\title{
Scientific Knowledge of University Students of Chile
}

\author{
Rubén Vidal Espinoza ${ }^{1}$, Emilio Rodríguez Macayo ${ }^{1}$, Rossana Gomez Campos ${ }^{2}$, \\ Rodrigo Ruay Garcés ${ }^{3}$, Sonia Isabel Muñoz ${ }^{4} \&$ Marco Cossio Bolaños ${ }^{5,6}$ \\ ${ }^{1}$ Universidad Católica Silva Henriquez, Santiago, Chile \\ ${ }^{2}$ Departamento de Diversidad e Inclusividad Educativa, Universidad Católica del Maule, Talca, Chile \\ ${ }^{3}$ Universidad de Playa Ancha, Valparaíso, Chile \\ ${ }^{4}$ Universidad de Los Lagos, Osorno, Chile \\ ${ }^{5}$ Departamento de Ciencias de la Actividad Física, Universidad Católica del Maule, Talca, Chile \\ ${ }^{6}$ Centro de Investigación Especializada, CINEMAROS, Arequipa, Perú \\ Correspondence: Rossana Gomez Campos, Universidad Católica del Maule, Av. San Miguel 3605, Talca, Chile.
}

Received: March 31, 2021

doi:10.5430/ijhe.v10n5p194
Accepted: May 18, 2021

Online Published: May 20, 2021

URL: https://doi.org/10.5430/ijhe.v10n5p194

\begin{abstract}
Scientific research is becoming increasingly important in higher education, as it helps students to understand scientific knowledge and provides tools to construct and interpret the meaning of what science provides. This descriptive study compares the use of scientific knowledge by university according to age, entrance route and type of establishment, and verifies the possible relationships between variables. A questionnaire measuring the use of scientific knowledge (information search, knowledge transfer and knowledge contribution) was administered to 187 university students. The results showed that there were no significant differences in the use of scientific knowledge by indicator and in the total scores among the three universities. A positive correlation was observed between age with knowledge contribution and type of school and knowledge transfer with type of school. It is concluded that the type of school could be relevant to obtain better results in the contribution and transfer of scientific knowledge, although age could also contribute.
\end{abstract}

Keywords: scientific knowledge, students, differential education

\section{Introduction}

In order to construct and interpret scientific knowledge, skills are needed at each of the stages of the scientific process. One of the distinctive characteristics of scientific knowledge is that it provides explanations for the behavior of the material world, expressed in terms of properties and characteristics (Millar, 2004).

Currently, scientific research has been gaining increasing importance within higher education (Aldana, 2012), since the objectives of science education aim to help students understand scientific knowledge as it corresponds to their needs, interests and abilities, as well as to develop an understanding of the scientific method (Millar, 2004).

In this context, students in Higher Education, regardless of major, must play an active role in taking on new knowledge. This implies that the student has to 'make sense' of the experiences and discourses of the paradigms and use these tools to construct and interpret the meaning of what science provides.

To construct scientific knowledge, it is necessary for students in higher education to acquire skills to interpret and solve problems, as well as to develop creative reasoning. This is a necessity that will allow them to understand the relevance of science in a given context

Therefore, scientific thinking, observation, creative thinking, interpretation, collection, data analysis and problem solving (Ausubel, 1964) are essential elements that students must know. This is relevant for decision making to address particular problems and propose potential solutions (Weis et al, 2005).

Currently, there has been an increased interest in studying attitudes, skills and the search for information (Cook, Selltiz, 1964; Nay, Croker, 1970; Fraser, 1977; Gauld, Hukins, 1980; Iliffe, 1994), in addition, several researches have been concerned with studying not only the search for information, but also the transfer of knowledge and the 
contribution of scientific knowledge in university students of educational sciences and specifically in the professional program of Special Education (Cossio-Bolaños et al., 2014; Rodríguez-Macayo et al, 2016).

In essence, science constitutes a strategic axis of human development, since it implies not only the strengthening of the critical capacity of a society (Alberts, 2008), but also of Higher Education students in general. Therefore, this study hypothesizes that there could be differences in the use of scientific knowledge in students of the special education program of three Chilean universities. For the search for information, the transfer of knowledge and the contribution of scientific knowledge are fundamental indicators for future professionals to aim at developing the necessary skills and attitudes to improve their productive activities associated with scientific research, technological development and innovation (Guerrero, 2007).

In fact, this information could be used in the initial training of future special education teachers as a means of critical reflection, which could constitute an increase in their scientific knowledge for the benefit of their professional training to consolidate their epistemological baggage of their specialty.

Therefore, the objectives of this study are: a) to compare the use of scientific knowledge by university, in higher education students considering the following variables: age, entrance route and type of establishment of origin, and b) to verify the possible relationships between variables.

\section{Methods}

\subsection{Type and Sample}

A descriptive study (comparative-correlational) was carried out. The sample selection was non-probabilistic (by convenience). A total of 187 female students were investigated. The age range was 17-26 years. The students belonged to the professional program of Special Education Pedagogy program at three Chilean universities: Universidad Católica Silva Henríquez -UCSH- (private), Universidad Católica del Maule- UCM- (private) and Universidad Los Lagos (public). Table 1 shows the variables that characterize the sample studied.

Table 1. Characteristics of the sample studied

\begin{tabular}{lcc}
\hline Variables & n & \% \\
\hline Ages & 137 & $73 \%$ \\
-19 years old & 42 & $22 \%$ \\
20-23 years old & 8 & $4 \%$ \\
+ 24 years old & & \\
University entrance psthway & 153 & $82 \%$ \\
University Selection Test (UST) & 9 & $5 \%$ \\
Validation of studies & 15 & $8 \%$ \\
Accompaniment and Effective Access Program (AEAP) & 10 & $5 \%$ \\
Other & & \\
Type of school in which they studied at the high school level & 74 & $40 \%$ \\
Public & 113 & $60 \%$ \\
Private & & \\
Universities & 78 & $42 \%$ \\
U. Silva Henríquez & 66 & $35 \%$ \\
U. Católica del Maule (UCM) & 43 & $23 \%$ \\
U. Los Lagos &
\end{tabular}

All university students enrolled in the second and third year participated in this study, and those who completed the instrument in its entirety were included. Those who did not authorize consent and did not attend the day of application of the instrument were excluded. The study was duly approved by the Ethics Committee of the Faculty of Education of the Universidad de Los Lagos and with the approval of the Direction of the Professional Program of the three mentioned Universities.

\subsection{Techniques and Procedures}

The survey technique was used for this study and the questionnaire proposed by Cossio-Bolaños et al (2013) was 
applied to measure the variable use of scientific knowledge. This instrument consists of 10 questions. It presents three indicators (Database, Knowledge Transfer and Contribution to knowledge). This instrument reflected an internal consistency of $r=0.80$, being interpreted with high reliability.

In each university, a professor of the area was in charge of applying the instrument. The instrument was applied in a classroom using the traditional method of pencil and paper. They were given instructions for filling out the questionnaire and were given 10-15 minutes to respond. During the measurement, each interviewer was accompanying the development and clarifying some doubts.

\subsection{Statistical Analysis}

Descriptive statistics calculations were performed, using frequency (fi), percentage analysis (\%), average (x) and standard deviation (SD). Cronbach's alpha was used for the reliability of the instrument. Differences between ages, universities and entry route were verified by one-way Anova and Tukey's post hoc test. Spearman was used for correlations between variables. The probability adopted in all cases was $\mathrm{p}<0.05$. The procedure was through bar graphs. Calculations were analyzed in Excel and SPSS 18 spreadsheets.

\section{Results}

The comparisons between universities and by indicator of the use of scientific knowledge can be seen in Table 2 . There were no significant differences between the three universities and in all the indicators studied.

Table 2. Comparison of knowledge use by indicator and university

\begin{tabular}{lcccccc}
\hline \multirow{2}{*}{ Indicators } & \multicolumn{2}{c}{ USH $(\mathbf{n}=\mathbf{7 8})$} & \multicolumn{2}{c}{ UCM $(\mathbf{n = 6 6})$} & \multicolumn{2}{c}{ ULL $(\mathbf{n = 4 3})$} \\
& $\mathbf{X}$ & $\mathbf{S D}$ & $\mathbf{X}$ & $\mathbf{S D}$ & $\mathbf{X}$ & SD \\
\hline Information search & 5,63 & 1,24 & 6,47 & 0,93 & 6,44 & 0,98 \\
Knowledge transfer & 6,01 & 1,23 & 6,06 & 1,11 & 5,98 & 1,01 \\
Knowledge contribution & 10,74 & 1,69 & 11,05 & 0,98 & 11,51 & 0,74 \\
Total & 22,38 & 2,68 & 23,58 & 1,94 & 23,93 & 1,84 \\
\hline
\end{tabular}

Legend: NS: Not significant, USH: Universidad Católica Silva Henríquez, UCM: Universidad Católica del Maule, UL: Universidad los Lagos, X: Average, SD: Standard Deviation.

Table 3 shows the results related to comparisons by age, entrance route and type of school. In all the variables studied, no significant differences were observed, both for the search for information, knowledge transfer and contribution of scientific knowledge. In general, these three indicators are similar regardless of age, entrance route and type of school in which they studied at the high school level.

Table 3. Comparison of the use of knowledge by age, entrance route and type of school in which they studied at the high school level

\begin{tabular}{lcccccccc}
\hline Variables & \multicolumn{3}{c}{ SI } & \multicolumn{3}{c}{ TK } & \multicolumn{3}{c}{ CK } & \multicolumn{2}{c}{ Total } \\
& $\mathbf{X}$ & SD & $\mathbf{X}$ & SD & $\mathbf{X}$ & SD & X & SD \\
\hline Ages & & & & & & & & \\
-19 years & 6,18 & 1,12 & 6,01 & 1,12 & 10,91 & 1,45 & 23,11 & 2,37 \\
20-23 years & 5,88 & 1,23 & 6,00 & 1,17 & 11,33 & 0,75 & 23,21 & 2,33 \\
+24 years & 6,13 & 1,25 & 6,25 & 1,28 & 11,38 & 0,74 & 23,75 & 2,12 \\
University entrance pathway & & & & & & & & \\
University Selection Test (UST) & 6,07 & 1,20 & 6,01 & 1,14 & 11,05 & 1,27 & 23,14 & 2,39 \\
Validation of studies & 5,89 & 0,78 & 6,00 & 1,12 & 10,89 & 1,27 & 22,78 & 2,73 \\
AEAP & 6,67 & 0,62 & 5,73 & 0,80 & 11,13 & 0,74 & 23,53 & 1,30 \\
Others & 6,10 & 1,10 & 6,60 & 1,43 & 10,60 & 2,41 & 23,30 & 2,75 \\
Type of school in which they studied at the high school level. & & & & & \\
Public & 6,23 & 1,10 & 5,85 & 0,99 & 10,88 & 1,39 & 22,96 & 2,31 \\
Private & 6,04 & 1,18 & 6,13 & 1,21 & 11,12 & 1,25 & 23,29 & 2,37 \\
\hline
\end{tabular}


Legend: SI: Search for information, TK: Transfer of knowledge, CK: Contribution of knowledge, X: Mean, SD: Standard deviation.

The relationships between study variables with the indicators of the use of scientific knowledge are shown in Figure 1. The type of school where the students have studied is positively related to the transfer and contribution of scientific knowledge, and age is only related to the contribution of knowledge. For the other variables, no relationship was observed. In general, although the relationships are low ( $<<0.05)$, age and type of school in which they studied at the high school level could be determinant for the contribution of knowledge and for the transfer of knowledge, respectively.

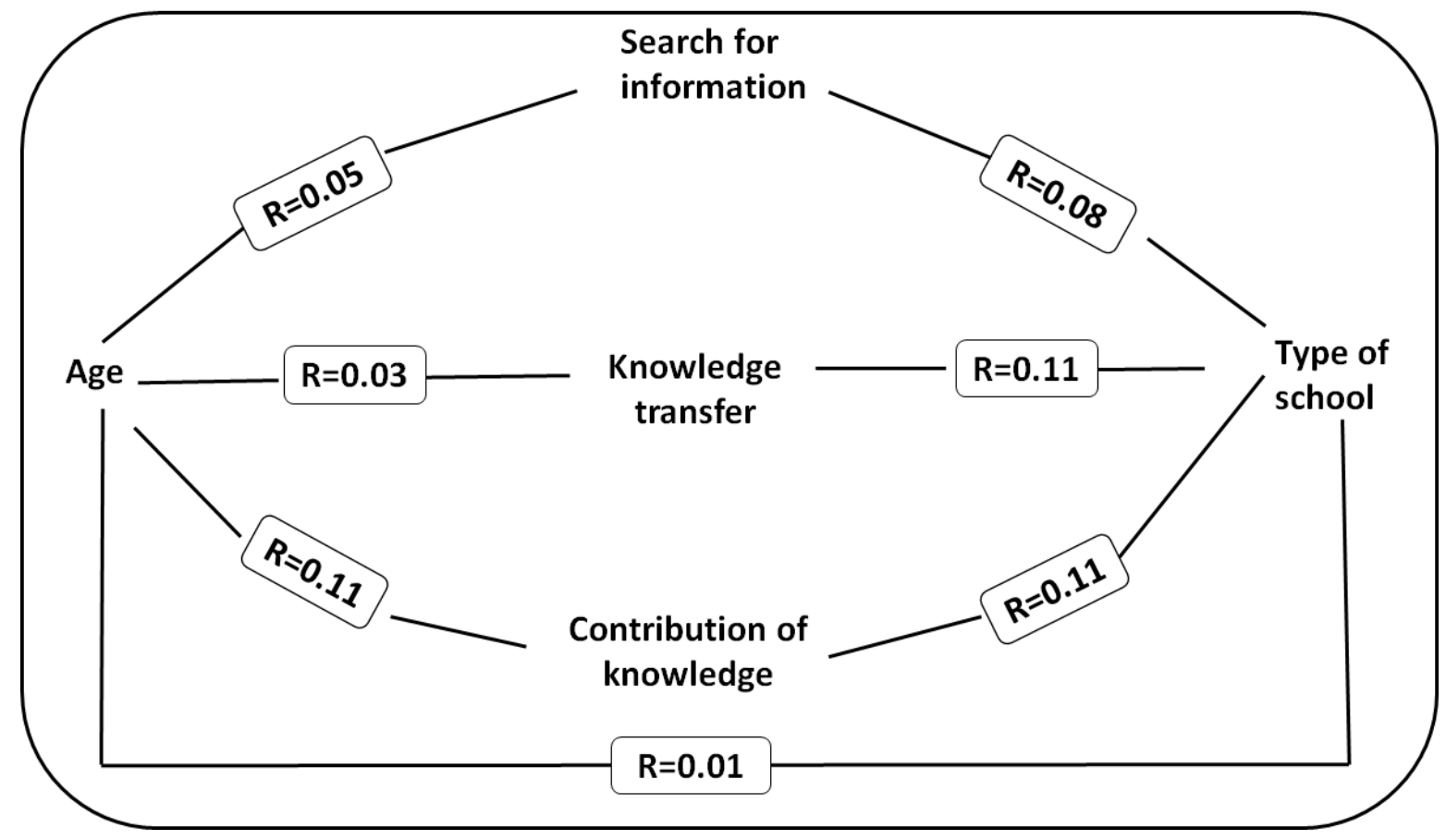

Figure 1. Relationship between age and type of school with indicators of the use of scientific knowledge $(\mathrm{p}<0.05)$

\section{Discussion}

The results of the study have shown that there were no significant differences in the use of scientific knowledge by university, age, entrance route and type of school in which they studied at the high school level. This means that special education students in the three Chilean universities reflect similar results in the search for information, contribution of knowledge and in the transfer of scientific knowledge. These findings are consistent with other studies conducted in higher education students (Cossio-Bolaños et al., 2013; Cossio-Bolaños et al., 2014; Rodríguez-Macayo et al., 2016).

Indeed, in recent decades, the focus in research on teaching and teacher education has shifted from observable behaviors and/or teaching skills to teachers' knowledge and beliefs, where the value of scientific knowledge is intended to promote the progress of science and technology, including can help to understand and transform the world (Yun-Na, 2017).

Currently there are challenges in the education of scientific knowledge, including the analysis of the curricula of professional programs, which could help higher education students to develop their own research in the first years of professional training. These changes generally help and encourage students to awaken interest in scientific knowledge, in which they can discover new advances and perspectives associated with their professional programs.

Therefore, it seems that meta-cognitive and mental analysis is necessary to promote learning skills (Hautamäki et al., 2002), especially those related to research, such as knowing how to search for information in databases, classifying types of research and/or articles relevant to their area, performing a critical reading of a publication, and the ability to transfer new knowledge to their daily interests. 
In essence, a solid knowledge of science may be relevant in the final years of the professional training, as craft knowledge about scientific knowledge is limited, since craft knowledge should try to overcome the idiosyncratic and superficial level of students' narratives (Van Driel et al., 1998) during their professional training process. Perhaps, this change could not only improve the investigative investments of the students, but also of the school teachers, so that this attitude installed in the curricula of the students of the special education professional program in the future, could be reflected in the classroom during professional practice and professional practice.

Some objectives that could be developed in the practical activity among students to develop the use of scientific knowledge are described by Millar, Abrahams (2009), where they emphasize that it is necessary: (a) help to know the world and understand main ideas, theories and models that science uses to explain facts and/or phenomena, (b) to learn how to use some piece, scientific apparatus and/or follow some standard scientific procedures and (c) develop students' understanding of the scientific approach to research (e.g., how to design an investigation, and evaluate data, process data to draw conclusions, evaluate the confidence with which these can be estimated).

As a second objective, this study verified the possible relationships between variables. For example, a weak positive correlation was observed between age and contribution of knowledge, and between the type of school in which they studied high school and contribution of knowledge. These relationships, although weak, could be an indicator that explains that, as university students increase in age, they consider that scientific knowledge contributes to their learning, to the creation and innovation of new didactic resources for teaching and learning, and to the improvement of students' school performance.

This means that students need experience during their professional training, where, for example, practical work is an effective tool to get students to remember the practical aspects of an experiment, since the ideas behind theoretical phenomena are rarely learned and remembered (Abrahams, Millar, 2008).

In that context, the meaning of practical work is described as helping students learn new scientific concepts, principles and models (Finnish National Board of Education, 2004), even countries such as Finland already inculcate experimentation from high school level to support students as they absorb new scientific concepts, principles and models (Finnish National Board of Education, 2003). Such curricular activities in the future could improve other indicators of scientific knowledge use such as information transfer and search. Although higher education is an important stage to ratify research motivation and is the basis of universities and colleges for a new economic era of society (Yun-Na, 2017).

A weak positive relationship was also observed between the type of school in which they studied at the high school level with knowledge transfer. This supposes that private schools may reflect some contents that can help to better understand the transfer of scientific knowledge.

The idea is that young university students should receive information with current contents related to their training as future special education teachers, especially that young people should be motivated to arouse natural curiosity and professional development. This should be accompanied by theory and practice, so that there is a balance in the use of time (Tiberghien, 1999) and a good analysis of the practical implications of the results obtained. For therein lies the real impact of research and its usefulness for future professionals, since later, as special education teachers, they will have to transfer knowledge to their future students, broadening their cultural knowledge background.

In essence, an adequate scientific training is one of the necessary requirements that must be offered to university students so that they can have an appropriate conception of science (Martín-Díaz, 2004). This is possible to install in the curriculum not only of the professional program of special education, but also of other related programs, since nowadays it is necessary for young university students to have mastery and present skills to search for information. This could improve the ability to solve complex problems during professional training (Cossio-Bolaños et al., 2014).

It is also relevant to highlight that University institutions, independent of their professional careers must show flexibility and adaptability to address complex problems related to science, however, they must recognize that there is currently a call for institutional change, in which the role of scientific knowledge and learning in the context of action and implementation is highlighted (Folke et al., 2005). Therefore, it is time to take on challenges and avoid future disconnections that hinder effective learning and change that science currently imposes.

Some limitations must be recognized in this study, for example, the socioeconomic condition and the participation in study groups by the students were not measured, including the instrumental mastery of some technological tools and the English reading ability would have allowed a greater approximation to our findings, as well as exploring relationships between variables that allow us to confront these results. However, being the first study carried out in Chile at the level of three universities, it is highlighted that future studies can take advantage of this information to 
compare with other local and/or international research and generate some changes in the professional program of special education.

\section{Conclusion}

This study concludes that the use of scientific knowledge of university students in the professional program of Special Education Pedagogy (information search, knowledge transfer and knowledge contribution) are similar by age, entrance route, type of school in which they studied at the high school level and university. In addition, the type of school in which they studied high school could be relevant for better results in scientific knowledge contribution and transfer. Although age could also improve knowledge contribution as part of the experience. These results suggest that universities should implement alternatives to train their students in information seeking. Further studies are needed to confirm these findings.

\section{References}

Abrahams, I., \& Millar, R. (2008). Does practical work really work? a study of the effectiveness of practical work as a teaching and learning method in school science. Journal of Science Education, 30(14), 1945-1969. https://doi.org/10.1080/09500690701749305

Alberts, B. (2008). Considering Science Education (editorial). Science, 319, 21, 1189. https://doi.org/10.1126/science.1157518

Aldana Marlen Gloria, (2012). La formación investigativa: su pertinencia en Pregrado. Revista Virtual Universidad Católica del Norte, 35, 367-379. http://www.redalyc.org/articulo.oa?id=194224362019

Ausubel, D. P. (1968). Educational psychology: A cognitive view. New York: Holt, Rinehart and Winston.

Cook, S., \& Selltiz C. (1964). Multiple indicator approach to attitude measurement. Psichol bull, 62(1), 36-65. https://doi.org/10.1037/h0040289

Cossio-Bolaños, M., Vidal-Espinoza, R., Yañez, A., \& Gómez-Campos, R. (2014). Uso del conocimiento científico de estudiantes de pre-grado en una facultad de ciencias de la educación. Multiciencias, 14(3), 304-310. http://www.redalyc.org/articulo.oa?id=90432809009

Cossio-Bolaños, M., Vidal-Espinoza, R., \& Valenzuela-Salazar, J. (2014). Validez y confiabilidad de un cuestionario para valorar el uso del conocimiento científico de docentes de educación especial. UCMaule Revista Académica, 47, 55-66. http://revistaucmaule.ucm.cl/article/view/14/143

Cossio-Bolaños, M., Monné de la Peña, R., Cornejo-Valderrama, C., Lepe, N., Vidal-Espinoza, R., \& Ferreira de Araujo, P. (2013). Construcción de un instrumento para medir el uso del conocimiento científico en alumnos de

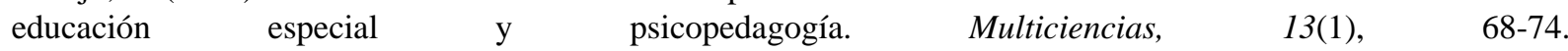
https://www.redalyc.org/pdf/904/90428348003.pdf

Finnish National Board of Education. (2003). National core curriculum for general secondary education intended for young people, 2003. URLhttp://www.oph.fi/download/47678_core_curricula_upper_secondary_education.pdf. Last accessed 31.1.2014.

Finnish National Board of Education. (2004). National core curriculum for basic education part iii: Chapters 7.4-7.9, 2004. URL http://www.oph.fi/download/47672_core_curricula_basic_education_3.pdf. Last accessed31.1.2014.

Folke, C., Hahn, T., Olsson, P., \& Norberg, J. (2005). Adaptive governance of social-ecological systems. Annu Rev Environ Resour, 30, 441-473. https://doi.org/10.1146/annurev.energy.30.050504.144511

Fraser, B. J. (1977). Selection and validation of attitude scales for curriculum evaluation. Sci Ed, 61(3), 317-30. https://doi.org/10.1002/sce.3730610307

Gauld, C. F., \& Hukins, A. A. (1980). Scientific Attitudes: A Review. Studies in Science Education, 7(1), 129-161. https://doi.org/10.1080/03057268008559877

Guerrero, M. (2007). Formación de habilidades para la investigación desde el pregrado. Acta Colombiana de Psicología, 10(2), 190-192. http://www.scielo.org.co/pdf/acp/v10n2/v10n2a18.pdf

Hautamäki, J., Arinen, P., Eronen, S., Hautamäki, A., Kupiainen, S., Lindblom, B., Niemivirta, M., Pakaslahti, L., Rantanen, P., \& Scheinin, P. (2002). Assessing Learning-to-Learn a Framework. Centre for Educational Assessment. University of Helsinki: National Board of Education in Finland.

Iliffe, S., \& Zwi, A. (1994). Beyond "clinical"? four-dimensional medical education. J R Soc Med. 87(9), 531-5. https://www.ncbi.nlm.nih.gov/pmc/articles/PMC1294771/ 
Martin Díaz, M. (2004). El papel de las ciencias de la naturaleza en la educación a debate. Revista Iberoamericana de Educación, 32(2), 1-14.

Millar, R., \& Abrahams I. (2009). Practical work: making it more effective. School Science Review, 91(334), 59-64. http://www.gettingpractical.org.uk/documents/RobinSSR.pdf

Millar, R. (2004). The role of practical work in the teaching and learning of science. High School Science Laboratories: Role and Vision, National Academy of Sciences, Washington, DC, University of York.

Nay, M., \& Croker, R. (1970). Science teaching and the effective attributes of scientists. J Res ScI Teach, 7(1), 59-67. https://doi.org/10.1002/sce.3730540115

Rodríguez-Macayo, E., Vidal-Espinoza, R., Dreyse-Muñoz, J. P., Sánchez-Pérez, C., Ruay, R., \& Cossio-Bolaños, M. (2016). Uso del conocimiento científico de estudiantes de pregrado de educación diferencia. UCMaule - Revista Académica, 51, 43-54.

Tiberghien, A. (1999). Labwork activity and learning physics - an approach based on modelling. In J. Leach \& A.C. Paulsen, editor, Practical Work in Science Research - Recent Research Studies, pages 176-194. Frederiksberg: Roskilde University Press.

Van Driel, J. H., Verloop, N., \& Vos, W. (1998). Developing Science Teachers' Pedagogical Content Knowledge. Journal of Research In Science Teaching, 35(6), 673-695. https://doi.org/10.1002/(SICI)1098-2736(199808)35:6<673: AID-TEA5>3.0.CO;2-J

Weiss, C. H., Murphy-Graham, E., \& Birkeland, S. (2005). An alternate route to policy influence: Evidence from a study of the Drug Abuse Resistance Education (D.A.R.E.) Program. American Journal of Evaluation, 26(1), 12-31. https://doi.org/10.1177/1098214004273337

Yun-Na, L. (2017). Practical Scientific Knowledge Education based on Herbert Spencer's "What Knowledge is of Most Worth? Journal of Mathematics Science and Technology Education, 13(7), 4291-4299. https://doi.org/10.12973/eurasia.2017.00836a

\section{Copyrights}

Copyright for this article is retained by the author(s), with first publication rights granted to the journal.

This is an open-access article distributed under the terms and conditions of the Creative Commons Attribution license (http://creativecommons.org/licenses/by/4.0/). 